\title{
ДЕКОРАТИВНЫЕ ДЕРЕВЬЯ И КУСТАРНИКИ ЗЕЛЕНЫХ НАСАЖДЕНИЙ ПОСЕЛКА ГОРОДСКОГО ТИПА КРАСНОГВАРДЕЙСКОЕ (РЕСПУБЛИКА КРЫМ) \\ Клименко Н.И. ${ }^{1}$, Потапенко И.Л. ${ }^{2}$
}

${ }^{I}$ ФГБУН «Ордена Трудового Красного Знамени Никитский ботанический сад - Национальный научный центр РАН», пгт Никита, г. Ялта, Российская Федерачия

${ }^{2}$ ФГБУН «Карадагская научная станиия им. Т.И. Вяземского - природный заповедник РАН», пгт. Курортное, г. Феодосия, Российская Федераџия e-mail:_klymenko.gnbs@mail.ru, ira_potapenko@mai.ru

Проведена дендрологическая инвентаризация зеленых насаждений поселка городского типа Красногвардейское в степном Крыму. Отмечены 40 видов и 4 декоративные формы деревьев и кустарников, относящиеся к 38 родам 23 семейств. Наиболее представлены в видовом отношении семейства: Rosaceae (5 видов), Oleaceae и Fabaceae (по 4 вида). Остальные семейства включают 1-3 вида. Четыре декоративные формы деревьев (Acer platanoides 'Globosum', Picea pungens 'Glauca`, Platycladus orientalis `Aurea`. Thuja occidentalis `Columna') отмечены единичными экземплярами. Наибольшее число видов (12, или 30,0\%) имеют широкий ареал, т.е. распространены в границах нескольких флористических областей. Из Средиземноморской и Атлантическо-Североамериканской областей происходят по 8 (20,0\%) видов, которые хорошо адаптированы к условиям региона. К аборигенной флоре Крыма относятся $7(17,5 \%)$ видов растений. Более половины $(65,9 \%)$ видового и формового разнообразия дендрофлоры составляют листопадные деревья (20 видов и форм, или 45,5\%) и кустарники (9 видов, или 20,4\%). Количество видов и форм вечнозеленых растений небольшое: хвойных деревьев 7 (15,9\%), хвойный кустарник 1 (2,3\%), вечнозеленых лиственных кустарников $2(4,5 \%)$ вида. Вертикальное озеленение практически отсутствует. Почти все используемые в современном озеленении древесные растения находятся в хорошем и удовлетворительном состоянии, что свидетельствует об их соответствии почвенноклиматическим условиям региона. Нами предложены 26 видов и 19 форм декоративных древесных растений, которые повысят эстетический уровень зеленых насаждений поселка и положительно повлияют на его общий архитектурный облик.

Ключевые слова: декоративные деревья и кустарники, состав дендрофлоры, поселок городского типа Красногвардейское, Степной Крым

\section{Введение}

Красногвардейское - поселок городского типа (пгт), центр Красногвардейского района и Красногвардейского сельского поселения Республики Крым. Район относится к плакорному ландшафтному уровню, который охватывает центральную часть равнинного Крыма, а также центральную и северо-восточную части Керченского полуострова. Особенности рельефа, создающие возможность беспрепятственной прокладки транспортных коммуникаций, наряду с особенностями умеренного климата, придают плакорному ландшатному уровню, который имеет высокий потенциал для дальнейшего промышленного и сельскохозяйственного использования, общерегиональную системную ценность, В пределах территории имеются также широкие возможности для развития градостроительства. На данный момент основные виды селитебных территорий здесь - это малые города и поселения сельского типа (Современные ландшафты Крыма..., 2009). Современные населенные пункты должны быть красивыми и комфортными, а их жители пользоваться максимальными удобствами и условиями, создающими здоровую, благополучную жизнь. Неотъемлемой составляющей любого населенного пункта являются зеленые насаждения. Изучение состава зеленых насаждений проводится во многих городах Крыма - Симферополе, Севастополе, Феодосии, Судаке (Потапенко и др., 2014; 34 
Репецкая, Парфенова, 2015; Коренькова, 2016; Потапенко, Клименко, Летухова, 2017). Однако эти исследования практически не затронули небольшие города и поселки, которые в настоящий момент все еще остаются вне зоны внимания в плане улучшения их «зеленой среды». Однако нет сомнения, что озеленительные работы здесь непременно будут востребованы. В связи с этим работникам зеленого строительства потребуется посадочный материал декоративных деревьев и кустарников, хорошо адаптированных к почвенно-климатическим условиям региона. К сожалению, в последние годы мы наблюдаем слишком «любительский» подход к данному вопросу, необоснованное использование различных декоративных растений, которые в первые же годы после посадки высыхают, вымерзают, утрачивают декоративность. Анализ современного состояния деревьев и кустарников отдельных населенных пунктов Степного Крыма поможет разработать научно обоснованный ассортимент древесных растений для данного региона с учетом новых гибридов, форм и сортов, а также современных тенденций зеленого строительства.

Цель настоящей работы - изучить состояние зеленых насаждений пгт Красногвардейское и предложить пути их оптимизации на основании определения видового и формового разнообразия дендрофлоры, проведения ее таксономического, ботанико-географического, биоморфологического анализа, частоты встречаемости видов и форм.

\section{Материалы и методы}

Климат района умеренный, засушливый. Среднегодовая температура воздуха колеблется от 10,0 до $10,9^{\circ} \mathrm{C}$; средний из абсолютных минимумов в феврале составляет $-17,6^{\circ} \mathrm{C}$, среднесуточная температура июля - от 22,0 до $23,7^{\circ} \mathrm{C}$, а период с температурой выше $10^{\circ} \mathrm{C}$ равен 185-190 дней. Средняя температура января изменяется от $-0,6$ до $-0,9^{\circ} \mathrm{C}$. Число дней со снежным покровом 20-30 в году. Количество осадков от 360 до 440 мм в год. Континентальность и засушливость климата усиливается за счет повышенного ветрового режима. В среднем за год насчитывается около 30 дней с сильным ветром, 6-9 - с пыльными бурями. Повторяемость засух (атмосфернопочвенных) в течение вегетационного периода составляет 30-50\%. Почвенный покров характеризуется господством черноземов южных обычных, мицелярно-карбонатных и мицелярно-высококарбонатных слабогумусированных, сформировавшихся на лессовидных породах. Совокупность черт географического положения территории определяет ряд положительных условий для жизни людей, в том числе для градостроительства и разнообразных видов хозяйственной деятельности, прежде всего сельскохозяйственной и рекреационной (Современные ландшафты Крыма..., 2009; Агрокліматичний довідник..., 2011).

Обследование зеленых насаждений пгт Красногвардейское проведено в сентябре 2017 г. и феврале - марте 2018 г. Обследуемые объекты: парк (5 га); улицы Тельмана, Ленина, Энгельса, Чкалова, Советская, Комсомольская; зеленый массив (примерно 0,8 га) и лесополоса (примерно 0,2 га) перед автовокзалом и школой; зеленые зоны у железнодорожного и автомобильного вокзалов, средней общеобразовательной школы, детской школы искусств; сквер «Крымская весна». Фрагменты озеленения поселка приведены на рис. 1.

При обследовании зеленых насаждений определялся вид (форма) деревьев и кустарников, возраст, таксационные показатели. Систематическое положение, объем и номенклатура таксонов приняты по С.К. Черепанову (1995) и А.В. Ене (2012). Для определения видовой принадлежности деревьев и кустарников, а также их декоративных (садовых) форм были использованы справочники по декоративным древесным породам (Дендрофлора України..., 2001; Дендрофлора України..., 2002; Дендрофлора України..., 2005). 


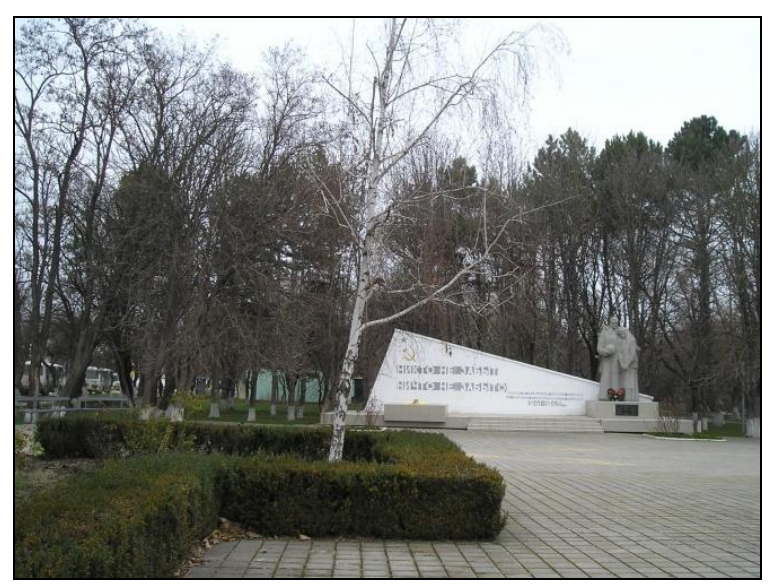

a

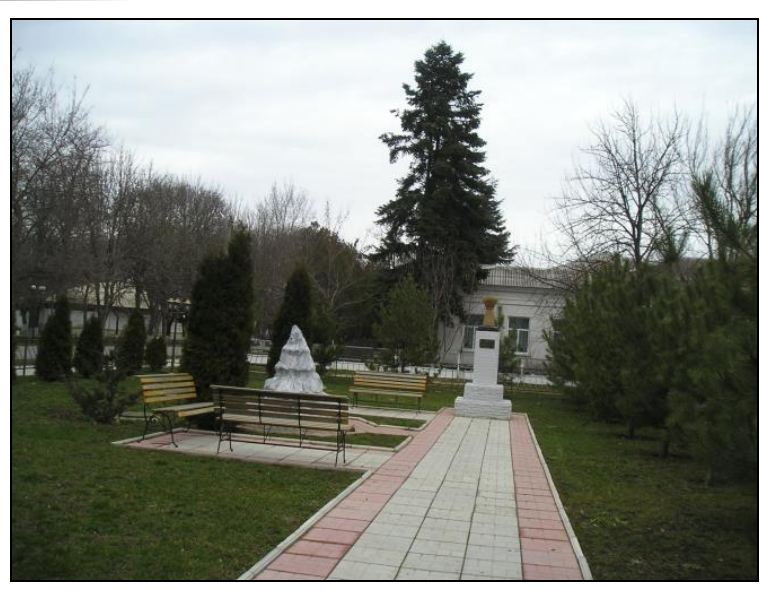

6

Рис. 1. Фрагменты озеленения пгт Красногвардейское: а - памятник воинам и гражданам района, погибшим в годы Великой Отечественной войны (Betula pendula Roth, Buxus sempervirens L.); б - сквер «Крымская весна» (Pinus nigra J.F. Arnold subsp. pallasiana (Lamb.) Holmboe, Thuja occidentalis `Columna`).

Ботанико-географический анализ проведен в соответствии с ботаникогеографическим делением мира (по флористическим областям) А.Л. Тахтаджяна (1978). Для частоты встречаемости вида (формы) приняты следующие условные обозначения: р - вид (форма) встречается редко (до 10 экземпляров во всех исследуемых объектах); ч - вид (форма) встречается часто (от 11 до 100 экз.) во всех объектах; м - вид (форма) массово используется в озеленении (более 100 экземпляров). При оценке частоты встречаемости Gleditschia triacanthos L не учитывались деревья, произрастающие в лесополосе, а лишь те, которые отмечены в поселке. Состояние растений оценивали по 4-балльной шкале (плохое, удовлетворительное, хорошее, отличное), предложенной Р.В. Галушко и Ю.С. Горак (2002).

Предложения по ассортименту декоративных деревьев и кустарников для использования в зеленых насаждений пгт Красногвардейское основаны на результатах данной работы, собственных многолетних исследований культивируемой дендрофлоры региона (Клименко и др., 2012; 2016), а также с учетом сведений и рекомендаций других авторов (Волошин, Кормилицын, 1960; Методические рекомендации..., 1980; Тростикова, Потемкина, 2017; Бескаравайный, Григорьев, Анненков, 1963). Растения аборигенной крымской флоры предлагаются с учетом их фитоценотических характеристик в Крыму (Исиков, Плугатарь, 2017).

\section{Результаты и обсуждение}

Красногвардейское (историческое название Курман-Кемельчи) расположено в 68 км от Симферополя. На территории поселка находится железнодорожная станция Урожайная. Через поселок проходит автодорога Симферополь - Москва. По данным переписи населения 2014 г. в пгт Красногвардейское проживало 11134 человека. Достоверных сведений о времени образования Курман-Кемельчи не обнаружено. В 1874-1875 гг. недалеко от поселка прошла Лозово-Севастопольская железная дорога. Была построена станция, вскоре превратившаяся в крупный пункт сбыта пшеницы отсюда в начале XX в. вывозилось свыше 1 млн. пудов зерна в год. В советский период Красногвардейский район был крупным промышленным центром Крыма с высоким уровнем развития промышленности: виноделия, консервно-сокового и мучного производства, маслоделия, производства строительных материалов. Строительство красногвардейской ветки Северо-Крымского канала дало новый импульс развитию сельского хозяйства в районе. С развитием промышленности и сельского хозяйства 36 
менялась инфраструктура поселка (с 1957 г. - поселок городского типа). В нем построены: новый жилой массив, больница, поликлиника, универмаг, другие бытовые здания, заасфальтированы дороги и тротуары, выросла сеть канализации и водопровода (История городов и сел..., 1974). С развитием инфраструктуры поселка проводилось и его озеленение, большинство зеленых зон образованы в 60-80-е годы прошлого века. Следовательно, многие древесные растения имеют возраст 35-50 лет. По данным отчета сотрудников Никитского ботанического сада в 1963 году в поселке насчитывалось 15 видов древесных растений: дуб черешчатый, акация белая, ясень обыкновенный, софора японская, гледичия трехколючковая, г. безколючковая, вяз гладкий, в. мелколистный, в. шершавый, в. перистоветвистый, шелковица (вид не указан), сирень обыкновенная, тополь черный, биота восточная, ель обыкновенная. Отмечено наличие в хорошем состоянии 75-80-летних деревьев акации белой, 40-50летних деревьев софоры японской, гледичии трехколючковой, дуба черешчатого, 3540-летних деревьев ясеня обыкновенного (Бескаравайный, Григорьев, Анненков, 1963). В настоящий момент на территории пгт Красногвардейское нами зарегистрированы 40 видов и 4 формы древесных растений (табл. 1).

Древесные растения пгт Красногвардейское

\begin{tabular}{|c|c|c|c|c|c|}
\hline $\begin{array}{c}\text { № } \\
\text { ПП }\end{array}$ & Вид (форма) & Семейство & $\begin{array}{c}\text { Частота } \\
\text { встре- } \\
\text { чаемости } \\
\end{array}$ & $\begin{array}{c}\text { Жизненная } \\
\text { форма }\end{array}$ & $\begin{array}{c}\text { Происхождение } \\
\text { (флористическая } \\
\text { область) } \\
\end{array}$ \\
\hline 1. & Acer platanoides `Globosum` & Sapindaceae & $\mathrm{p}$ & 1 & форма \\
\hline 2. & A. pseudoplatanus L. & $-/ /-$ & $\mathrm{p}$ & 1 & Цб \\
\hline 3. & Aesculus hippocastanum L. & Hippocastanaceae & ч & 1 & $\mathrm{Cp}$ \\
\hline 4. & Berberis vulgaris L. & Berberidaceae & $\mathrm{p}$ & 2 & Цб, Ср, ИТ; а \\
\hline 5. & Betula pendula Roth & Betulaceae & ч & 1 & Цб; а \\
\hline 6. & Buxus sempervirens L. & Buxaceae & ч & 6 & $\mathrm{Cp}$ \\
\hline 7. & Catalpa begnonioides Walter & Bignoniaceae & $\mathrm{p}$ & 1 & $\mathrm{AC}$ \\
\hline 8. & Celtis occidentalis L. & Cannabaceae & $\mathrm{p}$ & 1 & $\mathrm{AC}$ \\
\hline 9. & Cercis siliquastrum L. & Fabaceae & $\mathrm{p}$ & 2 & $\mathrm{AC}$ \\
\hline 10. & $\begin{array}{l}\text { Chaenomeles japonica (Thunb.) } \\
\text { Lindl. }\end{array}$ & Rosaceae & $\mathrm{p}$ & 2 & BA \\
\hline 11. & Cotoneaster horizontalis Decaisne & $-/ /-$ & $\mathrm{p}$ & 2 & ИТ \\
\hline 12. & Forsythia viridissima Lindl. & Oleaceae & $\mathrm{p}$ & 2 & $\mathrm{BA}$ \\
\hline 13. & $\begin{array}{l}\text { Fraxinus excelsior L. subs. } \\
\text { excelsior }\end{array}$ & $-/ /-$ & ч & 1 & Цб, Сp; a \\
\hline 14. & Gleditschia triacanthos L. & Fabaceae & $\mathrm{p}$ & 1 & $\mathrm{AC}$ \\
\hline 15. & Hedera helix L. & Araliaceae & $\mathrm{p}$ & 4 & Цб, Сp; a \\
\hline 16. & Hibiscus syriacus L. & Malvaceae & ч & 2 & ИТ \\
\hline 17. & Juglans regia L. & Juglandaceae & 4 & 1 & $\mathrm{Cp}$, ИТ, ВА \\
\hline 18. & Juniperus sabina $\mathrm{L}$. & Cupressaceae & $\mathrm{p}$ & 5 & Цб, Ср, ИТ; а \\
\hline 19. & J. virginiana L. & $-/ /-$ & ч & 5 & $\mathrm{AC}$ \\
\hline 20. & Ligustrum vulgare L. & Oleaceae & Macc & 3 & Цб, Сp; a \\
\hline 21. & Maclura pomifera (Rafin.) Schneid. & Moraceae & $\mathrm{p}$ & 1 & $\mathrm{AC}$ \\
\hline 22. & Mahonia aquifolium (Pursh) Nutt & Berberidaceae & ч & 6 & $\mathrm{OC}_{\Gamma}$ \\
\hline 23. & Morus alba $\mathrm{L}$. & Moraceae & $\mathrm{p}$ & 1 & ВА, ИТ \\
\hline 24. & $\begin{array}{l}\text { Parthenocissus quinquefolia (L.) } \\
\text { Planch }\end{array}$ & Vitaceae & $\mathrm{p}$ & 4 & $\mathrm{AC}$ \\
\hline 25. & Philadelphus coronarius L. & Hydrangeaceae & ч & 2 & $\mathrm{Cp}$ \\
\hline 26. & Picea pungens Engelm. & Pinaceae & $\mathrm{p}$ & 5 & $\mathrm{OC} \Gamma$ \\
\hline 27. & P.p.'Glauca` & $-/ /-$ & $\mathrm{p}$ & 5 & форма \\
\hline 28. & $\begin{array}{l}\text { Pinus nigra J.F. Arnold subsp. } \\
\text { pallasiana (Lamb.) Holmboe }\end{array}$ & $-/ /-$ & ч & 5 & $\mathrm{Cp} ; \mathrm{a}$ \\
\hline 29. & $\begin{array}{l}\text { Platanus x hispanica Mill. ex } \\
\text { Muenckh. }\end{array}$ & Platanaceae & $\mathrm{p}$ & 1 & гибрид \\
\hline
\end{tabular}


КЛИМЕНКО Н.И., ПОТАПЕНКО И.Л.

\begin{tabular}{|c|c|c|c|c|c|}
\hline $\begin{array}{l}\text { № } \\
\text { пп }\end{array}$ & Вид (форма) & Семейство & $\begin{array}{c}\text { Частота } \\
\text { встре- } \\
\text { чаемости }\end{array}$ & $\begin{array}{c}\text { Жизненная } \\
\text { форма }\end{array}$ & $\begin{array}{c}\text { Происхождение } \\
\text { (флористическая } \\
\text { область) }\end{array}$ \\
\hline 30. & Platanus orientalis $\mathrm{L}$. & $-1 /-$ & $\mathrm{p}$ & 1 & $\mathrm{Cp}$ \\
\hline 31. & Platycladus orientalis (L.) Franco & Cupressaceae & мacc & 5 & $\mathrm{BA}$ \\
\hline 32. & P.o.`Aurea` & $-1 /-$ & $\mathrm{p}$ & 5 & форма \\
\hline 33. & Prunus armeniaca $\mathrm{L}$. & Rosaceae & ч & 1 & ИТ \\
\hline 34. & P. cerasifera Ehrh. & $-1 /-$ & $\mathrm{p}$ & 1 & Сp, ИТ \\
\hline 35. & Robinia pseudoacacia L. & Fabaceae & ч & 1 & $\mathrm{AC}$ \\
\hline 36. & Salix caprea $\mathrm{L}$. & Salicaceae & $\mathrm{p}$ & 1 & Цб, ВА, Сp; а \\
\hline 37. & Santolina virens Mill. & Asteraceae & $\mathrm{p}$ & 10 & $\mathrm{Cp}$ \\
\hline 38. & $\begin{array}{l}\text { Styphnolobium japonicum } \\
\text { (L.)Schott }\end{array}$ & Fabaceae & ч & 1 & BA \\
\hline 39. & Spiraea x vanhouttei (Briot) Zab. & Rosaceae & ч & 2 & гибрид \\
\hline 40. & Syringa vulgaris $\mathrm{L}$. & Oleaceae & $\mathrm{p}$ & 2 & $\mathrm{Cp}$ \\
\hline 41. & Tilia tomentosa Moench. & Malvaceae & $\mathrm{p}$ & 1 & Цб, Сp \\
\hline 42. & Thuja occidentalis `Columna` & Cupressaceae & $\mathrm{p}$ & 5 & форма \\
\hline 43. & Ulmus pumila $\mathrm{L}$. & Ulmaceae & $\mathrm{p}$ & 1 & Цб, ВА, ИТ \\
\hline 44. & Yucca filamentosa $\mathrm{L}$. & Agavaceae & $\mathrm{p}$ & 9 & $\mathrm{AC}$ \\
\hline
\end{tabular}

Примечания к таблице. 1 - листопадное дерево, 2 - листопадный кустарник, 3 полувечнозеленый кустарник, 4 - листопадная лиана, 5 - хвойное дерево, 6 - хвойный кустарник, 7 - вечнозеленый лиственный кустарник, 8 - вечнозеленая лиана, 9 - юкка, 10 - полукустарник; а - аборигенная флора Крыма; флористические области: АC Атлантическо-Североамериканская, ВА - Восточноазиатская, ИТ - Ирано-Туранская, ОСг - Область Скалистых гор, Ср - Средиземноморская, Цб - Циркумбореальная.

Из таблицы 1 следует, что дендрофлора зеленых насаждений поселка включает 40 видов, относящихся к 37 родам 23 семейств. Наиболее представлены в видовом отношении семейства: Rosaceae (5 видов), Oleaceae и Fabaceae (по 4 вида). Остальные семейства включают 1-3 вида.

Из представителей семейства Rosaceae только два вида встречаются часто (Prunus armeniaca, Spiraea x vanhouttei), другие же (Chaenomeles japonica, Cotoneaster horizontalis, Prunus cerasifera) отмечены единично. Такое низкое флористическое разнообразие представителей данного семейства значительно снижает эстетический уровень зеленых насаждений, поскольку розоцветные являются источником красивоцветущих деревьев и кустарников. Различные их виды, декоративные формы и сорта из родов Chaenomeles, Cotoneaster, Crataegus, Cydonia, Malus, Prunus, Sorbus, Spiraea следует применять для создания декоративных парковых композиций и уличного озеленения. Садовые розы в поселке также используются недостаточно, несмотря на разработанный перспективный сортимент парковых, полуплетистых, полиантовых и миниатюрных роз, позволяющий применять их в различных ландшафтных композициях (Городняя, 2017).

Представители семейства Oleaceae - один вид дерева (Fraxinus excelsior) и три вида кустарников (Forsythia viridissima, Ligustrum vulgare, Syringa vulgaris). Представители рода ясень (Fraxinus) - декоративные, достаточно быстро растущие и долговечные деревья, широко используемые в озеленении городов и поселков. В пгт Красногвардейское встречаются 40-50-летние деревья, которые имеют высоту 10-12 м, диаметр ствола 40-50 см и находятся в удовлетворительном состоянии. Поэтому вполне целесообразно расширить здесь их видовое и формовое разнообразие. Различные виды, культивары и сорта родов Syringa и Forsythia также значительно улучшат эстетический облик поселка.

К представителям семейства Fabaceae относятся: робиния лжеакация (Robinia pseudoacacia), софора японская (Styphnolobium јаропісит), гледичия трехколючковая (Gleditschia triacanthos) и церцис европейский (Cercis siliquastrum). Робиния часто 
встречается в поселке. Отмечены 50-60-летние деревья в удовлетворительном состоянии и 30-летние деревья в хорошем состоянии (высота -8 м, диаметр ствола 45 см). Софора также встречается часто. Наибольшее количество деревьев софоры растет в парке (45 экз.), в сквере перед автовокзалом и школой (30 экз.). Гледичия в зеленых насаждениях встречается единично, но как отмечалось выше, она образует лесополосу с восточной стороны поселка. Деревья гледичии (возраст 40-50 лет) в лесополосе высажены двумя рядами (более 100 экз.), средняя высота 15 м и диаметр ствола 50-60 см. Растения находятся в хорошем и удовлетворительном состоянии. Церцис встречается единично, хотя он очень декоративен, красиво цветет и хорошо смотрится в группе, линейной посадке, а также солитером, особенно во время цветения.

В зеленых насаждениях практически отсутствуют декоративные формы деревьев и кустарников. Выявленные: Acer platanoides 'Globosum', Picea pungens 'Glauca', Platycladus orientalis ‘Aurea`. Thuja occidentalis ‘Columna` представлены единичными экземплярами. Состояние вышеперечисленных растений хорошее.

Учитывая региональные климатические и почвенные условия, мы предлагаем следующие декоративные формы древесных растений для применения в различных композициях. Отличающиеся от основного вида формой, окраской и размером цветков: Crataegus monogyna 'Rosea-plena', Deutzia x hybrida 'Strawberry fields', D. scabra 'Plena', Kerria japonica 'Pleniflora', Viburnum opulus f. roseum L., Weigela x hybryda 'Brystol Ruby. Отличающиеся формой кроны: Morus alba `Pendula', M. a. 'Pyramidalis', Fraxinus excelsior 'Pendula', Fraxinus excelsior f. aurea (Willd) Schelle, Styphnolobium japonicum 'Pendula', Robinia pseudoacacia 'Umbraculifera', Taxus baccata 'Fastigiata', T.b. 'Stricta'. Отличающиеся формой, окраской и размерами листьев: Berberis thunbergii `Purpurea', B. vulgaris ‘Atropurpurea', Sambucus nigra f. laciniata, S. n. 'Black Lace', Viburnum lantana var. variegatum Weston. Эти растения произрастают в зеленых насаждениях населенных пунктов региона, некоторые испытаны в дендрологической коллекции Степного отделения Никитского ботанического сада, в парке Карадагской научной станции. Все достаточно хорошо переносят как летнюю засуху, так и периодически повторяющиеся низкие зимние температуры, при этом в полной мере проявляя свои декоративные качества.

Из 44 видов и форм древесных растений в поселке массово произрастают только плосковеточник восточный (Platycladus orientalis) и бирючина обыкновенная (Ligustrum vulgare), на которые приходится только 4,5\% разнообразия дендрофлоры. Растения плосковеточника высажены во всех обследуемых зеленых зонах: в парке, на улицах, в скверах. Бирючина практически повсеместно используется для живых изгородей. Из нее, например, сформирован зеленый бордюр в парке и у здания школы. Часто используются 14 видов деревьев и кустарников, что составляет $(31,8 \%)$ видового и формового разнообразия дендрофлоры поселка.

\section{Деревья, часто используемые в озеленении.}

Можжевельник виргинский (Juniperus virginiana) часто встречается в насаждениях поселка (около 50 экз.) как одиночными растениями, так и в виде рядовой посадки (ул. Советская), где растения имеют довольно солидный возраст (50-60 лет), находятся в хорошем состоянии, достигают высоты 8-9 м, 20-25 см в диаметре. Сосна крымская (Pinus nigra subsp. pallasiana) также встречается как в рядовой посадке, так и отдельными деревьями (всего около 40 экз.). В парке сосны высажены двумя рядами: 30-40-летние деревья (20 экз.) в хорошем состоянии, имеют в среднем высоту 12 м, диаметр ствола 30-35 см, диаметр кроны 4 х 5 м; 30-50-летние деревья (15 экз.) также находятся в хорошем состоянии, имеют в среднем высоту 14 м, диаметр ствола - 35-40 см, диаметр кроны 6 х 6 м. 
Конский каштан обыкновенный (Aesculus hippocastanum) встречается одиночно и в виде рядовых посадок (более 40 экз.), все деревья в хорошем и удовлетворительном состоянии. Повреждение растений каштановой минирующей молью незначительное. В парке деревья (21 экз.) в возрасте 45 лет достигают высоты 14-17 м, диаметра ствола 25-35 см, диаметра кроны 5 х 8 м. Хорошо смотрится ряды каштанов, особенно во время цветения, у стелы воинам и жителям района, погибшим в годы Великой отечественной войны.

Робиния лжеакация (Robinia pseudoacacia) также встречается часто (более 40 экз.) - на улицах, в парке, но практически везде отдельными деревьями. Больше всего робинии на ул. Ленина: 30-летние деревья (12 экз.) со средней высотой 8 м, диаметром ствола 30-35 см и диаметром кроны 6 х 7 м в удовлетворительном состоянии.

Софора японская (Styphnolobium japonicum) на улицах встречается редко, но является доминирующей породой в других зеленых зонах поселка (всего более 60 экз.). Самые мощные деревья софоры (более 30 экз.) находятся в зеленом массиве недалеко от автовокзала: возраст 40-50 лет, высот 12-14 м, диаметр ствола 35-40 см, все в хорошем и удовлетворительном состоянии. В парке также много деревьев софоры (45 экз.). Здесь они в возрасте 40-50 лет достигают высоты 12 м, диаметр ствола 30-40 см, диаметр кроны 9 х 10 м, все в хорошем состоянии.

Береза повислая (Betula pendula), ясень обыкновенный (Fraxinus excelsior subs. excelsior), opex грецкий (Juglans regia), абрикос обыкновенный (Prunus armeniaca) встречаются реже (по 25-30 экз.). Как правило, это - одиночные деревья на улицах, ясени и березы также произрастают в парке и сквере. На ул. Ленина высажены молодые 4-х летние деревья березы (10 экз.) 2,5 м высоты, все в хорошем состоянии.

\section{Кустарники, часто используемые в озеленении.}

Вечнозеленые кустарники: самшит обыкновенный (Buxus sempervirens) и магония падуболистная (Mahonia aquifolium) встречаются одиночными растениями, в виде небольших групп, бордюров. Состояние растений хорошее и удовлетворительное. У самшита есть незначительные повреждения самшитовой огневкой. Листопадные кустарники: гибискус сирийский (Hibiscus syriacus), чубушник венечный (Philadelphus coronarius), спирея Ван-Гутта (Spiraea х vanhouttei), различные формы и сорта садовых роз используются во всех исследуемых объектах в виде отдельных растений, групп, живых изгородей. Все растения находятся в хорошем и удовлетворительном состоянии. Наибольшее число (28, или 63,6\%) видов и форм представлены единичными экземплярами, следовательно, не играют существенной роли в зрительном и эмоциональном восприятии зеленых насаждений поселка.

Более половины $(65,9 \%)$ видового и формового разнообразия дендрофлоры составляют листопадные деревья (20 видов и форм, или 45,5\%) и кустарники (9 видов, или 20,4\%). Все же их применение может быть расширено. Целесообразно высаживать здесь: кельрейтерию метельчатую (Koelreuteria paniculata Laxm.), акацию клейкую (Robinia viscosa Vent), ясень манный (Fraxinus ornus L.), боярышник полумягкий (Crataegus submollis Sarg.), сливу Писсарда (Prunus cerasifera var. pissardii Bail.), яблоню Недзвецкого (Malus niedzwetzkyana Dieck ex Koehne), что подтверждается как нашими исследованиями, так и рекомендациями других авторов (Методические рекомендации..., 1980).

Видовой состав хвойных растений значительно беднее: деревьев $7(15,9 \%)$ видов и форм, кустарник (Juniperus sabina) 1 (2,3\%), хотя именно хвойные выполняют важную роль в формировании и восприятии культурного ландшафта, особенно в зимнее время. Можно разнообразить ассортимент такими видами, как пихты испанская и греческая (Abies pinsapo Boiss., A. cephalonica Loundn.), лжетсуга Мензиса (Pseudotsuga menziesii (Mirb.) Franco), можжевельник обыкновенный (Juniperus 
communis L.), тис ягодный (Taxus baccata L.), которые прошли многолетнее испытание в дендрологической коллекции Степного отделения Никитского ботанического сада. Как отмечалось выше, в поселке отмечены только 2 вида вечнозеленых лиственных кустарников: самшит (Buxus sempervirens) и магония (Mahonia aquifolium), а также полувечнозеленый кустарник (Ligustrum vulgare), характеристика которых приведена выше. Вертикальное озеленение практически отсутствует. Вечнозеленая лиана (Hedera helix) произрастает в нескольких местах на территории школы и не создает необходимого декоративного эффекта. Листопадная лиана (Parthenocissus quinquefolia) также встречается редко. По нашему мнению, следует увеличить долю хвойных деревьев и кустарников в зеленых насаждениях поселка, что значительно повысит его эстетическую привлекательность и улучшит микроклимат. Применение вечнозеленых лиственных кустарников в значительной мере ограничивается низкими зимними температурами. Для вертикального озеленения можно использовать испытанные в Степном Крыму кампсис укореняющийся (Campsis radicans (L.) Seem.), глицинию китайскую (Wisteria sinensis (Sims) Sweet), адаптированные виды и сорта р. Lonicera, Clematis.

Ботанико-географический анализ показал, что наибольшее число видов $(12$, или $30,0 \%$ ) имеют широкий ареал, т.е. распространены в границах ареала нескольких флористических областей. Например: Fraxinus excelsior, Hedera helix, Ligustrum vulgare, Tilia tomentosa относятся к циркумбореально-средиземноморской флоре. Из Атлантическо-Североамериканской области происходят $8(20,0 \%)$ видов, которые хорошо адаптированы к условиям региона. Из Средиземноморской области происходят $8(20,0 \%)$ видов, которые также хорошо адаптированы. Однако при дальнейшей интродукционной работе следует учитывать тот факт, что растения средиземноморской флоры, как правило, недостаточно морозостойкие. Доля видов, происходящих из других флористических областей незначительна. Только 7 (17,5\%) видов древесных растений, произрастающих в пгт Красногвардейское, относятся к аборигенной крымской флоре. Их применение может быть расширено привлечением таких видов, как: каркасы (Celtis australis L., C. glabrata Steven ex Planch.), вязы (Ulmus glabra Huds., U. laevis Pall., U. minor Mill.), рябины (Sorbus aucuparia L., S. domestica L., S. torminalis (L.) Crantz, S. umbellate (Desf.) Fritsch), липы (Tilia cordata Mill., T. dasystyla Steven, T. euchlora C.Koch,), скумпия (Cotinus coggygria Scop), испытанные в разные годы в Степном Крыму. Эти растения аборигенной крымской флоры обладают необходимыми экологическими свойствами, при этом они декоративны, долговечны, физиономически соответствуют природному ландшафту.

\section{Выводы}

1. Дендрофлора пгт Красногвардейское включает 40 видов и 4 формы, относящихся к 38 родам 23 семейств. Наиболее представлены в видовом отношении семейства: Rosaceae (5 видов), Oleaceae и Fabaceae (по 4 вида). Остальные семейства включают 1-3 вида. Отмечены четыре декоративные формы деревьев: Acer platanoides 'Globosum', Picea pungens 'Glauca', Platycladus orientalis 'Aurea'. Thuja occidentalis 'Columna', которые представлены единичными экземплярами. Из 44 видов и форм древесных растений массово произрастают только 2 (4,5\%), часто используются 14 $(31,8 \%)$ видов и форм деревьев и кустарников. Остальные $28(63,7 \%)$ видов и форм встречаются редко.

2. Наибольшее число видов (12, или 30,0\%) имеют широкий ареал, т.е. распространены в границах нескольких флористических областей. Из Средиземноморской и Атлантическо-Североамериканской областей происходят по 8 (20,0 \%) видов, которые хорошо адаптированы к условиям региона. Только 7 (17,5\%) 
видов относятся к аборигенной флоре Крыма. Более половины $(65,9 \%)$ видового и формового разнообразия составляют листопадные деревья (20 видов и форм, или $45,5 \%$ ) и кустарники (9 видов, или 20,4\%). Доля вечнозеленых растений низкая: хвойных деревьев 7 (15,9\%), хвойный кустарник 1 (2,3\%); вечнозеленых лиственных кустарников $2(4,5 \%)$ вида. Вертикальное озеленение практически отсутствует.

3. В настоящее время видовой состав декоративных деревьев и кустарников значительно выше (более, чем на 60\%), чем в 1963 году. Практически все используемые в современном озеленении пгт Красногвардейское древесные растения находятся в хорошем и удовлетворительном состоянии, что свидетельствует об их соответствии почвенно-климатическим условиям региона, правильному подбору ассортимента. Предложенные выше виды и декоративные формы деревьев и кустарников повысят эстетический уровень зеленых насаждений поселка и положительно скажутся на его общем архитектурном облике.

\section{Список литературы}

1. Агрокліматичний довідник по автономній республічі Крим (1986-2005 рр.) / за редакцією в. о. начальника ЦГМ в АРК О.І. Прудка та к. геогр. н. Т.І. Адаменко. Довідкове видання. - Т. 1. - Сімферополь: ЦГМ в АРК, 2011. - 121 с.

2. Бескаравайный М.М., Григорьев А.Г., Анненков А.А. Годовой отчет за 1963 г. по теме 4 «Разработка дендрологических основ паркового строительства в поселках совхозов и колхозов древесных и кустарниковых пород для их озеленения». Никитский ботанический сад, Ялта, 43 с. Рукопись.

3. Волошин М.П., Кормилищын А.М. Закладка сельских парков и озеленение поселков, совхозов и колхозов. - Симферополь: Крымиздат, 1960. - 98 с.

4. Галушко Р.В., Горак Ю.С. О результатах интродукции древесных растений в Евпаторийском дендропарке // Бюллетень Никитского ботанического сада. - 2002. Вып. 84. - С. 53-57.

5. Городняя E.B. Биологические особенности представителей рода Rosa L. коллекции Ботанического сада им. Н.В. Багрова Таврической академии Крымского федерального университета им. В.И. Вернадского: автореф. дис... на соиск. учен. степени канд. биол. наук. - Ялта: ГБУ РК «Никитский ботанический сад национальный научный центр», 2017. - 22 с.

6. Дендрофлора Украӥни. Дикорослі та культивовані дерева й кущі. Голонасінні / за ред. М.А. Кохна, С.І. Кузнецова. - К.: Вища школа, 2001. - 207 с.

7. Дендрофлора України. Дикорослі та культивовані дерева й кущі. Покритонасінні. Частина I: довідник / за ред. М.А. Кохна. - К.: Фітосоціоцентр, 2002. - 448 с.

8. Дендрофлора України. Дикорослі та культивовані дерева й кущі. Покритонасінні. Частина II: довідник / за ред. М.А. Кохна, Н.М. Трофименко. - К.: Фітосоціоцентр, 2005. $-716 \mathrm{c}$.

9. Ена А.В. Природная флора Крымского полуострова. - Симферополь: Н. Оріанда, 2012. $-231 \mathrm{c}$.

10. Исиков В.П., Плугатарь Ю.В. Дикорастущие деревья и кустарники Крыма. Симферополь: ИТ «АРИАЛ», 2017. - 324 с.

11. История городов и сел УССР. Крымская область. Красногвардейский район [предс. редкол. Л. Д. Солодовник]. - Киев: Главная редакция Украинской советской энциклопедии АН УССР, 1974. - С. 331-357.

12. Клименко Н.И., Плугатарь Ю.В., Мороз С.А. Древовидные интродуценты в степном Крыму // Биоразнообразие и устойчивое развитие / М-лы II Междунар. науч.практич. конф. (12-16 сентября 2012, г. Симферополь). - Симферополь: ТНУ им. В.И. Вернадского, 2012. - С. 369-371. 
13. Клименко Н.И., Плугатарь Ю.В., Клименко О.Е. Основные древесные паркообразующие породы в озеленении степного Крыма // Охрана, восстановление и изучение степных экосистем в XXI веке / М-лы Междунар. науч.-практич. конф., посвящ. 90-летию со дня основания заповедника «Хомутовская степь» (24-26 августа 2016 г., Донецк). - Донецк: Донецкий ботанический сад, 2016. - С. 111-113.

14. Коренькова O.O. Роль фитонцидноактивных древесно-кустарниковых пород в садово-парковых композициях на примере ПКИО им. Ю.А. Гагарина (г. Симферополь) // Ученые записки Крымского федерального университета им. В.И. Вернадского. Сер. «Биология. Химия». - 2016. - Т. 2 (68), № 4. - С. 37-43.

15. Методические рекомендации по подбору деревьев и кустарников для озеленения степного и предгорного Крыма / составил А.Г. Григорьев, ред. Н.К. Секуров. Ялта: ГНБС, 1980. - 27 с.

16. Потапенко И.Л., Клименко Н.И., Летухова В.Ю. Декоративные древесные растения в зеленых насаждениях Юго-Восточного Крыма (на примере г. Судак) // Вестник Башкирского государственного аграрного университета. - 2017. - № 2. - С. 113119.

17. Потапенко И.Л., Летухова В.Ю., Розенберг О.Г., Диордиенко Е.В. Декоративные древесные растения г. Феодосии // Ученые записки Таврического национального университета им. В.И. Вернадского. Серия "Биология, химия". - 2014. - Т. 27 (66). № 5 (Спецвыпуск). - С. 119-132.

18. Репечкая А.И., Парфенова М.А. Сквер 70-летия Великой Отечественной войны (Севастополь): современное состояние и проектные предложения // Экосистемы. 2015. - Вып. 1. - С. 41-52.

19. Современные ландшафты Крыма и сопредельных акваторий / науч. ред. Е.А. Позаченюк. - Симферополь: Бизнес-Информ, 2009. - 672 с.

20. Тахтаджян А.Л. Флористические области Земли. - Л.: Наука, 1978. - 248 с.

21. Тростикова О.А., Потемкина Н.В. Проблемы озеленения сельского поселения во втором степном агроклиматическом районе Крыма // Известия Оренбургского государственного аграрного университета. - 2017. - № 3(65). - С. 216-219.

22. Черепанов C.K. Сосудистые растения России и сопредельных государств (в пределах бывшего СССР). Русское издание. - СПб: Мир и семья, 1995. - 992 с.

\section{ORNAMENTAL TREES AND SHRUBS IN GREEN SPACES OF THE URBAN-TYPE SETTLEMENT KRASNOGVARDEYSKOE (REPUBLIC OF CRIMEA) Klymenko N.I. ${ }^{1}$, Potapenko I.L. ${ }^{2}$ \\ ${ }^{1}$ Of the Order of the Red Banner Nikitsky Botanical Gardens - National Scientific Center of the Russian Academy of Sciences, Nikita, Yalta, Russian Federation \\ ${ }^{2}$ T.I. Vyazemsky Karadag Scientific Station - Nature Reserve of RAS, Kurortnoe, Feodosia, Russian Federation e-mail: klymenko.gnbs@mail.ru, ira_potapenko@mai.ru}

Dendrological inventory of green spaces of the urban-type settlement Krasnogvardeyskoe in the steppe Crimea was carried out. We noted 40 species and 4 decorative forms of trees and shrubs belonging to 38 genera of 23 families. The most representative families are: Rosaceae ( 5 species), Oleaceae and Fabaceae (4 species each). Other families include 1-3 species. Four decorative forms of trees (Acer platanoides ‘Globosum, Picea pungens 'Glauca', Platycladus orientalis `Aurea, Thuja occidentalis 'Columna') are represented by single plants. The greatest number of species (12, or $30.0 \%)$ has a wide origin, i.e. distributed on the territory of several floristic regions. There are $8(20.0 \%)$ species from the Mediterranean and the Atlantic-North American floristic regions that are well adapted to the conditions of the region. Only 7 (17.5\%) species belong to the aboriginal flora of the Crimea. More than half $(65.9 \%)$ of the species and form diversity are deciduous trees (20 species and forms, or $45.5 \%$ ) and shrubs (9 species, or $20.4 \%$ ). The proportion of evergreen plants is low: coniferous trees 7 
$(15.9 \%)$, coniferous shrubs $-1(2.3 \%)$, evergreen deciduous shrubs $2(4.5 \%)$. Vertical landscaping is practically absent. Almost all arboreal plants used are in good and satisfactory state in modern greenery of Krasnogvardeyskoe that indicates their corresponding with the soil and climatic conditions of the region. We have proposed 26 species and 19 forms of ornamental arboreal plants to increase the greenery aesthetic level of the settlement and positively affect its overall architectural appearance.

Key words: ornamental trees and shrubs, composition of dendroflora, urban-type settlement Krasnogvardeyskoe, steppe Crimea

Поступила в редакциию 16.07.2018 2. 